

Journal homepage: http://www.journalijar.com
Journal DOI: 10.21474/IJAR01

INTERNATIONAL JOURNAL

OF ADVANCED RESEARCH

RESEARCH ARTICLE

\title{
PSYCHOANALYTIC FEMINISM - A TOOL TO STUDY THE WORKS OF VIRGINIA WOOLF AND SYLVIA PLATH USING BEAUVOIR'S THE SECOND SEX.
}

Soundarya K $\mathbf{R}^{1}$, Dr K Shanthi Chitra ${ }^{2}$.

1. Research Scholar, Faculty of Science and Humanities, SRM University, Kattankulathur, Chennai 603203

2. Head, Department of English, Faculty of Science and Humanities SRM University, Kattankulathur, Chennai 603203

\section{Manuscript Info}

\section{Abstract}

\section{Manuscript History:}

Received: 18 March 2016

Final Accepted: 19 April 2016

Published Online: May 2016

Key words:

*Corresponding Author

Soundarya K R.

Copy Right, IJAR, 2016,.. All rights reserved.

Virginia Woolf and Sylvia Plath, British and American writers respectively, share commonalities, even though they are from different origins. Phobia, trauma, suicidal instincts, mental instability, are common issues that all the studies have tried to prove. According to Beauvoir, these problems (the above mentioned), currently adverse in the society, are not just because of the oppression of the male counterparts but the inner ingrained patterns, from which women and men are unable to come out. "Woman is a female to the extent that she feels herself as such" (69 Beauvoir). These stereotypical imprints in the psyche of a woman, marks the beginning of her trauma. Unable to move into the world of transcendence and unable to move out of the immanence, a woman begins her struggle and is left in a void.

Plath's only semi autobiographical novel is The Bell jar. The novel is an instigated plot of Esther Greenwood under mental instability. Under Internship, Esther Greenwood moves to the New York City and she gets herself into the clutches of the lifestyle. Unable to untie the knots around her, she falls prey to the instability and she involves herself in abnormal activities (according to the society). She talks about electrocution and Rosenberg and she assumes herself being in the situation of a Jew and she imagines all men to be German dictators. She tries to escape from their clutches virtually and she falls sick often. She befriends Doreen and Betsy, and she parties with them. The clutches she is into is her own mind, her own self, struck in the air tight Bell Jar, the stereotypes, in which she was immersed in. One such is her party with Doreen, where she is unable to choose her drink.

"I'll have a vodka," I said

The man looked at me more closely. "With anything?"

"Just plain," I said. "I always have it plain."

"I thought I might make a fool of myself by saying I'd have it with ice or gin or anything. I'd seen a vodka as once, just a glass full of vodka standing in the middle of a snowdrift in a blue light, and the vodka looked clear and pure as 
water, so I thought having a vodka plain must be all right. My dream was someday ordering a drink and finding out it tasted wonderful." (10 Plath)

Beauvoir explains the same situation in which women and men are struck. Men, according to Beauvoir, look at women as providers and the Other. Men are supposed to take and women are to give. The concept of defloration is as such viewed in such a way that, women give away themselves for the love and men take them as possessions. In The Bell jar, Esther Greenwood, resists taking this idea and revolts within herself. In chapter seven she expresses to herself, "I couldn't stand the idea of a woman having to have a single pure life and a man being able to have a double life, one pure and one not" (77 Plath). Beauvoir also revolts the idea in her The Second Sex, "it is not the women, but the men who control the world" (314 Beauvoir). But recent lifestyle of women, universally, is not much confined to the household.

Virginia Woolf gave the readers a family picture of the Victorian times. The family was her mostly used society like Plath, and her works express different facets of life. In Woolf's semi-autobiographical novel To the Lighthouse, the characters in the house seem to have lost the connection between them. Mrs Ramsay is seen with her youngest son James Ramsay and is always seen being just a mother to him. Mr Ramsay tries to overpower Mrs Ramsay in every way possible and he tries to subdue Lily Briscoe, a painter, even though he's an artist and aesthetician himself. Being a sympathy seeker, Mr Ramsay tries to humiliate Mrs Ramsay, for which she replies and responds politely and subtly. He never tried to recognize her and never did he care to realize her recognition for him. All he managed to do was to assert himself all through the novel. "At that moment, he said, "very fine' to please her and pretended to admire her flowers." (62 Woolf)

Lily Briscoe, the painter in the novel To the Lighthouse of Woolf, is equally harassed mentally and she seems to be totally contradictory to Mrs Ramsay. Lily does not have interest in marriage, while Mrs Ramsay looks at marriage as an inevitable part in life and she seeks a groom for Lily. Mr Bankes, a middle aged widower is sought as a groom and he tried to be happy with her and wanted to talk to her with love and that which interests her, especially painting. Mr Tansley, a young philosopher who stays with the Ramsays, terribly hurt Lily for her painting and her way of thinking. In the words of Mr Tansley, "Women can't paint, women can't write..." (42 Woolf)

Beauvoir gives us a similar account of lifestyle, by throwing light on different facets of women and men in different lifestyles. She gives an account of how women try to catch the attention of men. "Men's stares flatter and hurt her simultaneously; she wants only what she shows to be seen: eyes are always too penetrating" (373 Beauvoir). According to the novels, the women seem to be very conscious about their virginity. Lily Briscoe and Esther Greenwood in the novels of Woolf and Plath respectively, care much about Virginity. They wish to be 'taken' by a man and in the same time revolt against. The biology of the female, that is the feminine quality of a woman is inevitably feminine, that she incorporates certain amount of stereotypes. This helps the women to bring themselves out of the Bell Jar. Lily Briscoe wanted to attract Mr Bankes and is simultaneously afraid of him getting attracted towards her and eventually is afraid of subjecting herself to marriage. In the same way, Esther Greenwood wanted to attract and gets attracted towards Buddy Willard. Only after she came to know about his personal affair, did she start hating him. Then she began to become an active extrovert in sex and she started finding a sex mate for her and found a math professor Irwin. Trying to come of the stereotypes, the women in the novels have called themselves feminists and tried to expose the archetypal setup. But the biology was itself a question. When Plath witnessed the virginity break, she felt extremely afraid, came home and cried in pain. Looking at her blood flowing, Joan, friend and asylum mate of Esther, becomes insane and commits suicide. The haunting marriage was provocative in the characters of the novels. In Beauvoir's The Second Sex, she quotes Stekel's words, about the women who try to kill themselves after witnessing or experiencing a sexual act. "It sometimes happens that a lofty-minded girl will commit suicide after such an event, or the whole edifice of her amorous imagination collapses because the ideal stands revealed as a brutish animal" (373 Beauvoir).

Esther, in The Bell Jar always tries to dump herself in "clear hot water," for some time, for her to come back to normalcy, because when she is depressed all that comes to her mind is death. She feels great about the hot water, like the religious people feel about the 'Holy water.'

I said to myself: "Doreen is dissolving; Lenny shepherd is dissolving, Frankie is dissolving. New York is dissolving, they are dissolving, they are all dissolving away and none of them matter anymore. I don't know them, I have never 
known them and I am very pure. All that liquor and sticky kisses I saw and the dirt that settled on my skin on the way back is turning into something pure." (19 Plath)

In Beauvoir's The Second Sex, she discusses the stereotypical imprints that stay with both men and women from their childhood. These deeply ingrained patterns are the cause for many advantages and disadvantages. Between the age of one and two, the child (both son and daughter in this context), aggressively kisses and caresses the mother and the daughter is equally strong as her brothers till the age of twelve (approx.). Through the years of growing, the daughter and the son are given certain imprints to hold forever in their minds. The boy is persuaded to think that he is superior and the pride in his manhood is instilled in the boy. The abstract idea is taken forward to the concrete idea, that is, the idea of the phallus (penis). This is not because of his mindscape, but of the people around him. "The child is persuaded that more is demanded of boys because they are superior; to give him courage for the difficult path he must follow..." (299 Beauvoir).

Women or girls are also subjected to such stereotypical stalemate and they are even more hampered by the very thought that she is a woman. Unlike man, a woman is extremely into these stereotypes, from which she is unable to come out. All her roles, a daughter, a sister, a wife, a mother, a grandmother and a woman of the society (immediate or distant), have the haunting stereotypes as her barrier. Man perceives her through the barriers (stereotypes) and so does a woman look in a man and herself. The double edged knife is the society (family or the external society) and her own self. A woman's life is risky mentally and physically in many patriarchal societies. These stereotypes definitely hold an identity in itself. The identity of a gender itself is pursued through a stereotype. The notion of stereotypes is negated throughout the feminist writings, but the stereotypical imprints create an identity.

In the novel The Bell Jar, Esther feels incompetent with the male counterparts of the novel, where she feels totally struck in a 'Bell Jar' airtight unable to breathe the air of New York. Unable to undergo a kind of settlement, that is, unable to assert and recognize, she completely feels damned in Earth and seeks the help of either Hot Water or suicide. She feels as if she is in the 'Sealed Jar,' which is expressed by her several times in the novel.

“The silence depressed me. It wasn't the silence of silence. It was my own silence. I knew perfectly well the cars were making noise, and people in them and behind the lit windows of the buildings were making noise, and the river was making a noise, but I couldn't hear a thing." (17 Plath)

Esther, during the internship, expresses her instability due to these stereotypes and a woman like Esther, being born in a circumstance and being educated in the other, feels quite shifted in sense. Due to the loss of the parental guidance, she feels completely lost and the society (New York) makes her insane. Her continual acceptance of immanence and her persistent approach towards transcendence creates an imbalance.

“Whenever I'm sad I'm going to die, or so nervous I can't sleep, or in love with somebody I won't be seeing for a week, I slump down just so far and then I say: "I'll go take a hot bath." I meditate in the bath. The water needs to be very hot, so hot you can barely stand putting your foot in it. Then you lower yourself inch by inch, till the water's up to your neck." (18 Plath)

Mrs Ramsay in To the Lighthouse is also struck in the immediate society (family) and is unable to put herself away from the stereotypes, as a mother and as a wife (stereotypically). Mr Ramsay is as well unable to shift himself from the pigeonhole, even though he is a rationalist in the eyes of the society. Mrs Ramsay is the character, who portrays the struggle between transcendence and immanence, the fight between assertion and recognition. The journey to the interior is emphasized now and then in the novel and the shift between reality and fantasy is also seen.

"Beneath it is all dark, it is all spreading, it is unfathomably deep; but now and again we rise to the surface and that is what you see us by. Her horizon seemed to her limitless. There were all places she had not seen... This core of darkness could go anywhere, for no one saw it." (55 Woolf)

In several instances the women and men are altogether unable to shift between transcendence and immanence, the swap between assertion and recognition is almost negligible. The tension between the two (assertion and recognition) seems to be lost and the problems in the society (family as well as the public sphere) crop up. If the swap between assertion and recognition, the tension between, transcendence and immanence is sought, when the roles (Subject/Object, Self/Other) are interchanged at certain instances (reciprocal relation), the advent of issues in 
the society may reduce. This is asserted by Beauvoir in her work, The Second Sex. "Each aspires to impose its sovereignty upon the other. If both are able to resist this imposition, there is created between them a reciprocal relation, sometimes in enmity, sometimes in amity, always in a state of tension" (93 Beauvoir). The idea of reciprocal relation or intersubjectivity is dealt by many psychoanalytic feminists, who do not voice out gender polarity and equality, but gender polarity, its limitations with both men and women and a few possible solutions.

\section{Works Cited:-}

1. Plath, Sylvia. The Bell Jar. London: Faber and Faber Limited, 1966. Print.

2. Woolf, Virginia. To the Lighthouse. New Delhi: Peacock Books, 1927. Print.

3. Beauvoir, Simone de. The Second Sex. London: Vintage Books, 1997. Print. 